\title{
Watershed Scale Response to Climate Change-Flint River Basin, Georgia
}

\section{Introduction}

General Circulation Model (GCM) simulations of future climate through 2099 project a wide range of possible scenarios (Intergovernmental Panel on Climate Change, 2007). To determine the sensitivity and potential effect of long-term climate change on the freshwater resources of the United States, the U.S. Geological Survey Global Change study, "An integrated watershed scale response to global change in selected basins across the United States" was started in 2008. The long-term goal of this national study is to provide the foundation for hydrologically based climatechange studies across the nation.

Fourteen basins for which the Precipitation Runoff Modeling System (PRMS) has been calibrated and evaluated were selected as study sites. PRMS is a deterministic, distributedparameter watershed model developed to evaluate the effects of various combinations of precipitation, temperature, and land use on streamflow and general basin hydrology. Output from five GCMs and four emission scenarios were used to develop an ensemble of climate-change scenarios for each basin. These ensembles were simulated with the corresponding PRMS model. This fact sheet summarizes the hydrologic effect and sensitivity of the PRMS simulations to climate change for the Flint River Basin at Montezuma in Georgia (U.S. Geological Survey streamflow-gaging station 02349500; fig. 1) presented in the project summary report (Markstrom and others, 2012) and a journal article (Hay and others, 2011).

\section{Study Area}

The upper portion of the Flint River flows unimpeded by major impoundments for about 320 river kilometers and provides habitat for biologically diverse communities that have been lost in the impounded reaches of many other rivers in the eastern United States. River shoal habitat in the upper Flint River supports a variety of native fishes, mussels, and aquatic plants. The upper Flint River watershed supplies water to a growing population in the Atlanta metropolitan area and is a major recreational resource for the region. Urban growth in the headwaters, which encompass a portion of the Atlanta metropolitan area, and increasing demands for offstream water-use, will affect future flow regimes in the upper Flint River.

The U.S. Geological Survey selected "Water availability for ecological needs in the Upper Flint River Basin, Georgia" as a national priority science thrust program for 2006-2008. The Flint River science project is part of a federally funded program to address key national science priorities including landslides/ debris flows, fire science, integrated landscape monitoring, and water availability. The fundamental purpose of this project is to advance the science needed to specify the hydrologic conditions necessary to support flowing-water ecosystems; information that is critical for management of water resources. This project uses the PRMS model developed for the Upper Flint River Basin, a 7,511-square kilometer $\left(\mathrm{km}^{2}\right)$ basin located above U.S. Geological Survey streamflow-gaging station 02349500 at Montezuma, in Macon County, Georgia as described by Viger and others (2010).

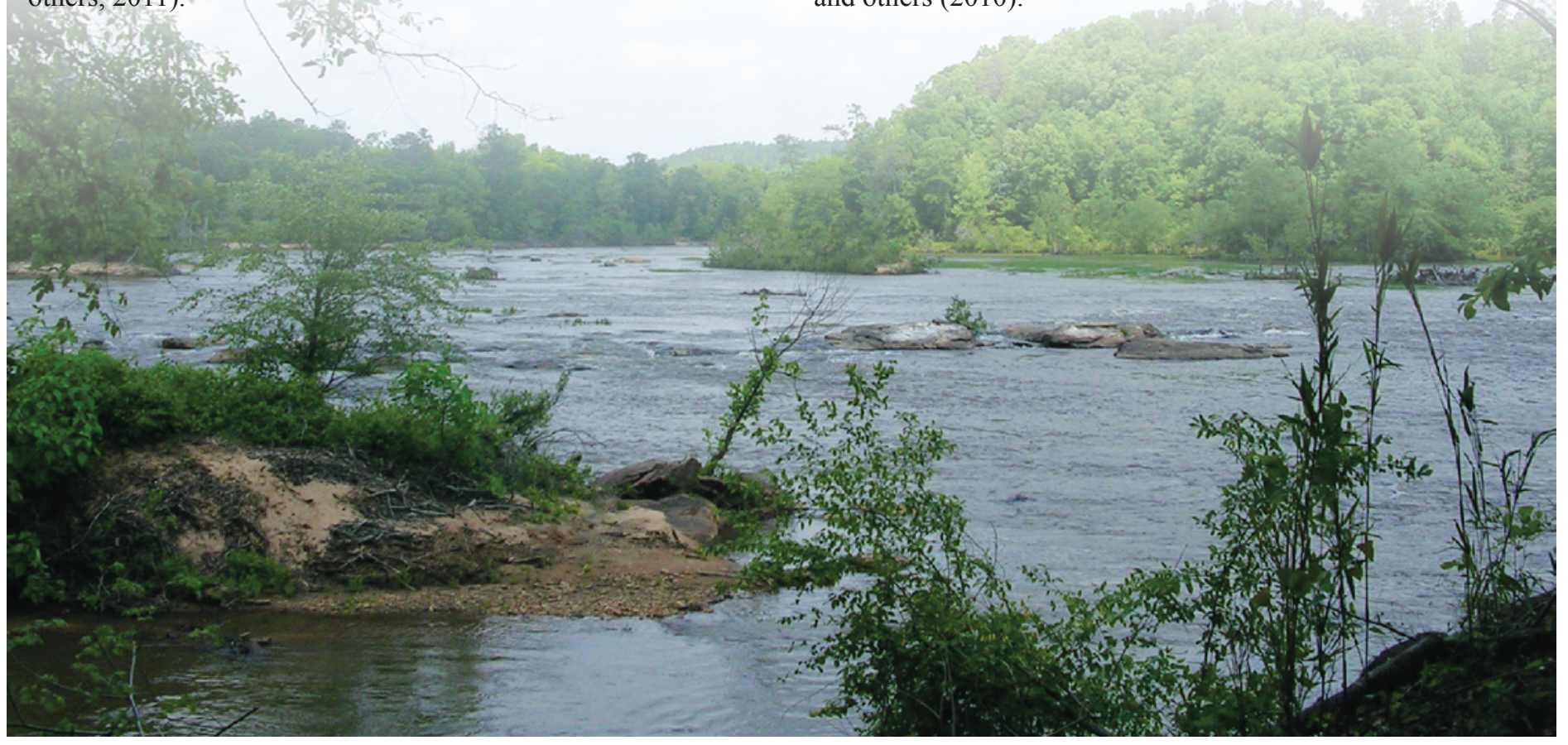




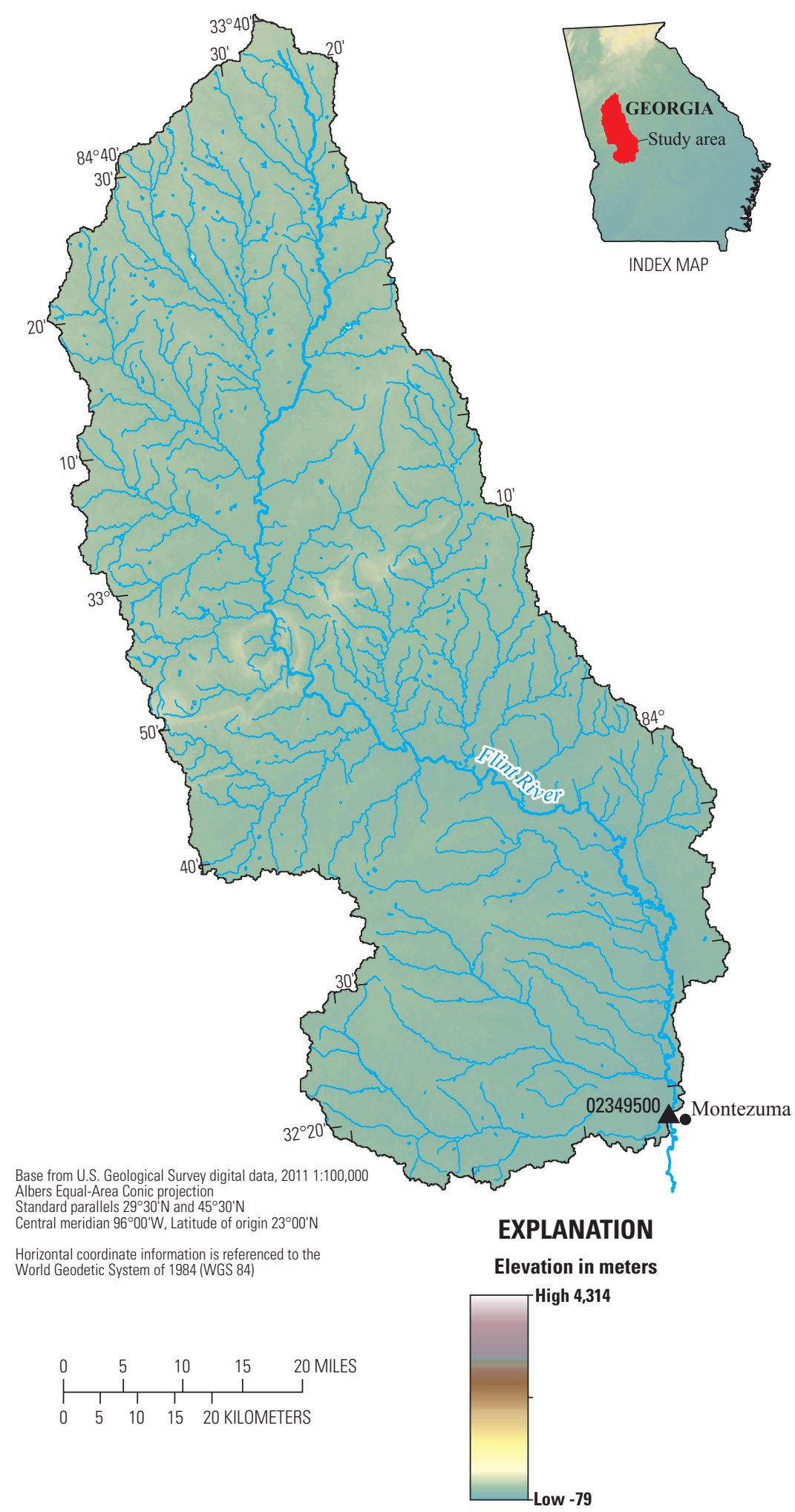

02349500 U.S. Geological Survey streamflowgaging station and identifier

Figure 1. Precipitation Runoff Modeling System study locations, Flint River Basin, Georgia, and location of U.S. Geological Survey streamflow-gaging station 02349500 with a drainage area of 7,511 square kilometers and elevation range from 90-286 meters. 


\section{General Circulation Models}

Given the uncertainty in climate modeling, it is desirable to use more than one GCM to obtain a range of potential future climatic conditions. Monthly precipitation and temperature output from five GCMs were processed (table 1).

Table 1. General Circulation Model (GCM) projections used in this study.

\begin{tabular}{ll}
\hline \multicolumn{1}{c}{ GCM } & \multicolumn{1}{c}{ Center and country of origin } \\
\hline BCC-BCM2.0 & Bjerknes Centre for Climate Research, Norway \\
CSIRO-Mk3.0 & Australia's Commonwealth Scientific and Industrial Research Organization, Australia \\
CSIRO-Mk3.5 & Australia's Commonwealth Scientific and Industrial Research Organization, Australia \\
INM-CM3.0 & Institute for Numerical Mathematics, Russia \\
MIROC3.2 & National Institute for Environmental Studies, Japan \\
\hline
\end{tabular}

The GCM outputs were obtained from the World Climate Research Programme's Coupled Model Intercomparison Project phase 3 multi-model dataset archive, which was referenced in the Intergovernmental Panel on Climate Change Fourth Assessment Special Report on Emission scenarios (Intergovernmental Panel on Climate Change, 2007). For each GCM, one current (water years 1988-1999) and three future emission scenarios were used and are described in table 2.

Table 2. Climate-change emission scenarios simulated by the General Circulation Models in this study.

\begin{tabular}{ll}
\hline \multicolumn{1}{c}{ Emission scenario } & \multicolumn{1}{c}{ Description/assumptions } \\
\hline 20C3M & 20th century climate used to determine baseline (1989-1999) conditions \\
A1B & $\begin{array}{c}\text { Rapid economic growth, a global population that peaks in mid-21st century and rapid introduction of new and } \\
\text { more efficient technologies with a balanced emphasis on all energy sources } \\
\text { Convergent world, with the same global population as Emission scenario A1B, but with more rapid changes in } \\
\text { economic structures toward a service and information economy that is more ecologically friendly }\end{array}$ \\
A2 & Heterogeneous world with high population growth, slow economic development, and slow technological change \\
\hline
\end{tabular}

Climate-change fields were derived by calculating the change in climate from current (water years 1988-1999) to future conditions simulated by each GCM. The 20C3M simulation for water years 1988-1999 was used to represent current climatic conditions. This 12 -year period of record was chosen based on the overlap of the available historical records from the 14 basins included in the national study. Climate change fields (percentage changes in precipitation and degree changes in temperature) were computed for 12-year moving window periods (from 2001-2099) using the 20C3M (1988-1999) and the A1B, B1, and A2 emission scenarios. A 12-year moving window, starting in 2001 and ending in 2099, results in 1,320 future scenarios $[(88,12$-year climatologies, 1 per year starting with 2001-2012 and ending with 2088-2099) x (3 emission scenarios) x (5 GCMs)].

Climate-change scenarios were generated for PRMS by modifying PRMS precipitation and temperature inputs with the mean monthly climate change fields derived from the GCMs, resulting in 1,320 PRMS-input files. Table 3 shows the change (slope) and adjusted $\mathrm{R}^{2}$ (adjR2) for the least squares fit to the trend line for selected output variables from the PRMS projections. The slope indicates the change in the selected variable by year. The adjusted $\mathrm{R}^{2}$ value gives an indication of the variability in the central tendency of the trend line.
Figure 2 shows a summary of the projected range in 11-year moving mean daily values of maximum temperature (fig. $2 A$ ), minimum temperature (fig. $2 B$ ), and precipitation (fig. $2 C$ ) by emission scenario. The first year of each 12-year simulation was used as PRMS initialization and is not included in the results. The three solid-colored lines indicate the 11-year moving mean values (x-axis indicates center of 11-year window) for the three future emission scenarios (central tendency of the five GCMs for each emission scenario). The projected range shown for each emission scenario indicates the range of potential future climatic conditions simulated by the five GCMs. All GCM simulations project steady increases in maximum and minimum temperature (table 3), with uncertainties associated with these GCM projections increasing with time (fig. 2). Both maximum and minimum temperatures show the smallest projected annual changes for the B1 emission scenario. Unlike temperature, projected changes in precipitation project both increases and decreases over time, with an overall negative trend projected for the A2 and A1B emission scenarios (table 3). The wide range in the precipitation projections indicates a large amount of uncertainty, especially in the $\mathrm{A} 2$ and $\mathrm{A} 1 \mathrm{~B}$ emission scenario projections (fig. $2 C$ ). 

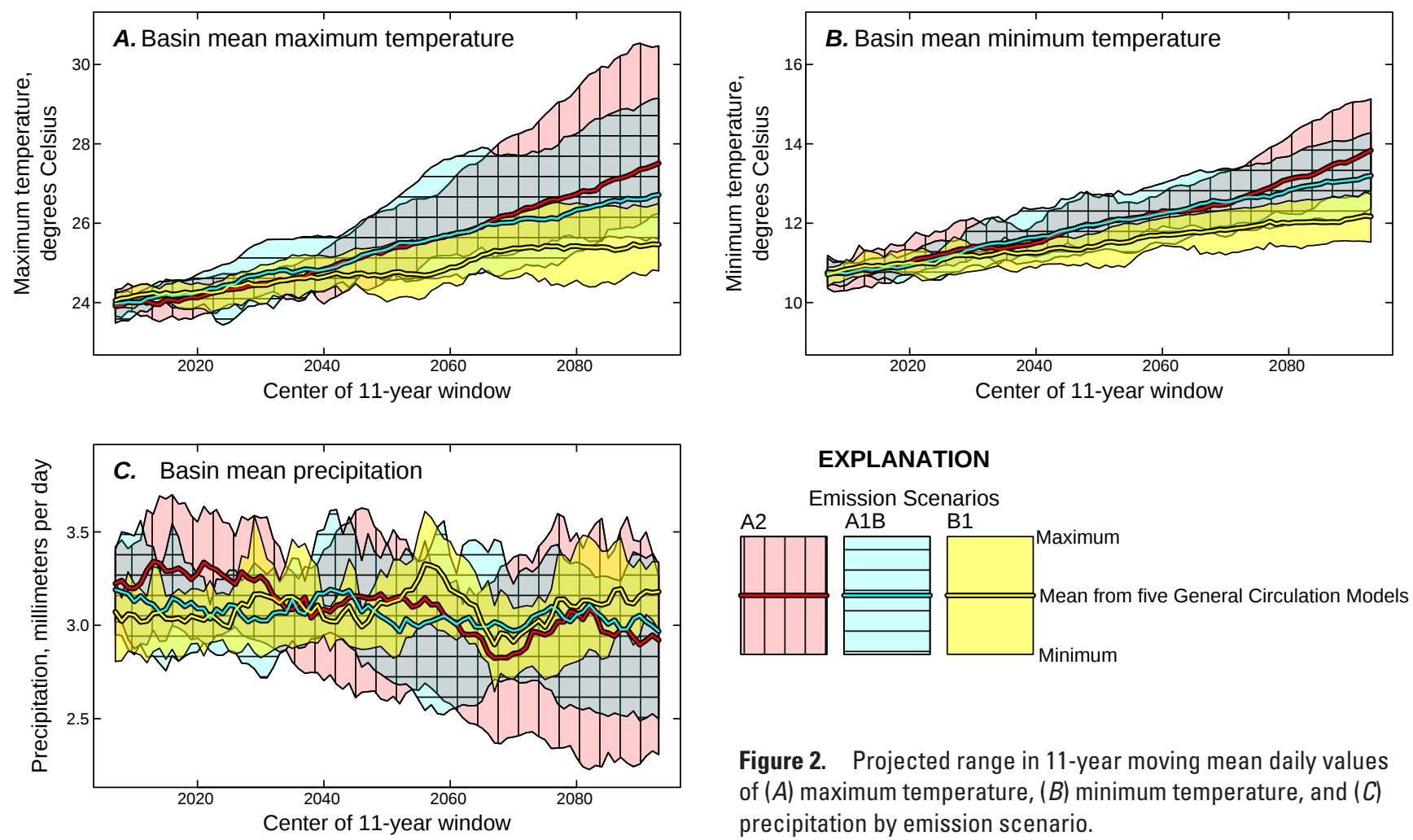

Figure 2. Projected range in 11-year moving mean daily values of $(A)$ maximum temperature, $(B)$ minimum temperature, and $(C)$ precipitation by emission scenario.

Table 3. Projected change by year (slope) and adjusted $\mathrm{R}^{2}$ (adjR2) based on the central tendencies of the five General Circulation Models for the three carbon emission scenarios for selected Precipitation Runoff Modeling System (PRMS) output variables.

[Blue indicates a significant negative trend and yellow indicates a significant positive trend $(\mathrm{p}<0.05)$ accounting for lag-1 autocorrelation]

\begin{tabular}{|c|c|c|c|c|c|c|}
\hline \multirow{2}{*}{ PRMS output variable } & \multicolumn{2}{|c|}{$\begin{array}{c}\text { Emission scenario } \\
\text { A1B }\end{array}$} & \multicolumn{2}{|c|}{$\begin{array}{c}\text { Emission scenario } \\
\text { A2 }\end{array}$} & \multicolumn{2}{|c|}{$\begin{array}{c}\text { Emission scenario } \\
\text { B1 } \\
\end{array}$} \\
\hline & slope & $\operatorname{adjR2}$ & slope & adjR2 & slope & $\operatorname{adjR2}$ \\
\hline Maximum temperature in degrees Celsius & 0.034 & 0.99 & 0.043 & 0.98 & 0.018 & 0.95 \\
\hline Minimum temperature in degrees Celsius & 0.030 & 1.00 & 0.034 & 0.98 & 0.017 & 0.99 \\
\hline Precipitation in millimeters per day & -0.0014 & 0.35 & -0.0047 & 0.72 & 0.0008 & 0.04 \\
\hline Streamflow in cubic meters per second & -0.2162 & 0.76 & -0.4359 & 0.83 & -0.0373 & 0.02 \\
\hline Surface runoff in cubic meters per second & -0.05164 & 0.73 & -0.11173 & 0.82 & -0.00588 & -0.00 \\
\hline Subsurface flow in cubic meters per second & -0.04200 & 0.66 & -0.09640 & 0.79 & -0.00282 & -0.01 \\
\hline Groundwater flow in cubic meters per second & -0.12264 & 0.81 & -0.22784 & 0.86 & -0.02873 & 0.06 \\
\hline Soil moisture in millimeters per day & -0.2076 & 0.95 & -0.2995 & 0.97 & -0.0902 & 0.56 \\
\hline
\end{tabular}

\section{Results}

PRMS simulates spatially distributed streamflow, components of flow (surface, subsurface, and groundwater), and many other hydrologic components of interest. Figure 3 shows a summary of PRMS-simulated basin mean values of streamflow, and corresponding components of flow by emission scenario. The central tendencies of the PRMS simulations using the five GCMs projects significant decreases in mean annual streamflow and corresponding flow components for the $\mathrm{A} 1 \mathrm{~B}$ and A2 emission scenarios (table 3), though the uncertainties associated with these projections are large.
Changes in streamflow can be examined on a monthly basis (fig. 4). The red lines in figure 4 show PRMS-simulated mean monthly baseline conditions (1989-1999) for streamflow. The box plots represent the range in the mean monthly outputs for the five GCMs and three scenarios for 2030 (green, 2025-2035), 2060 (tan, 2055-2065) and 2090 (blue, 2085-2095). By the end of the 21 st century, results project the largest decreases in streamflow during the highest flow months (January through April and July), with a high degree of variability associated with the magnitude of these decreases. 

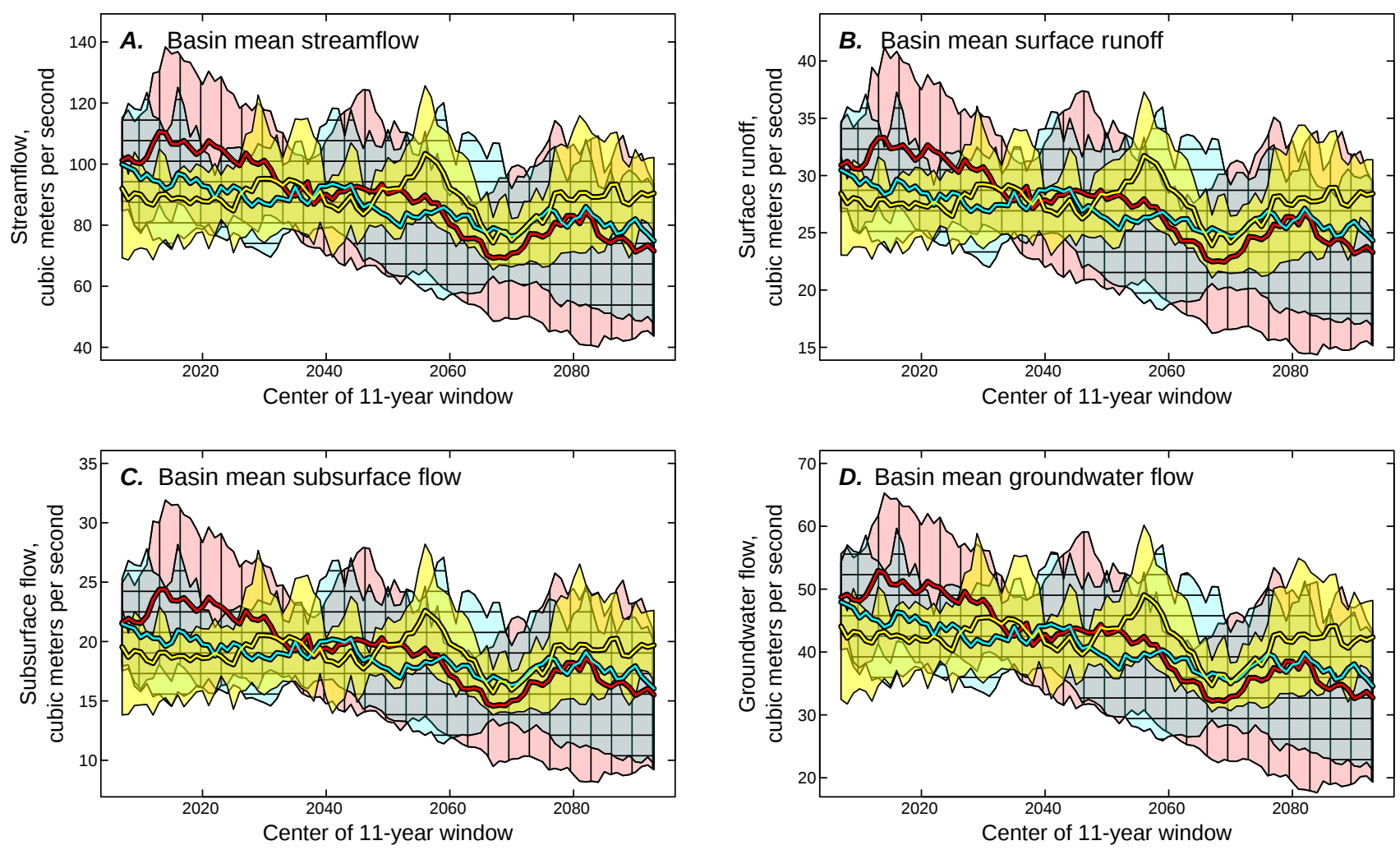

Figure 3. Projected range in 11-year moving mean daily values of $(A)$ streamflow, $(B)$ surface runoff, $(C)$ subsurface flow, and $(D)$ groundwater flow by emission scenario.
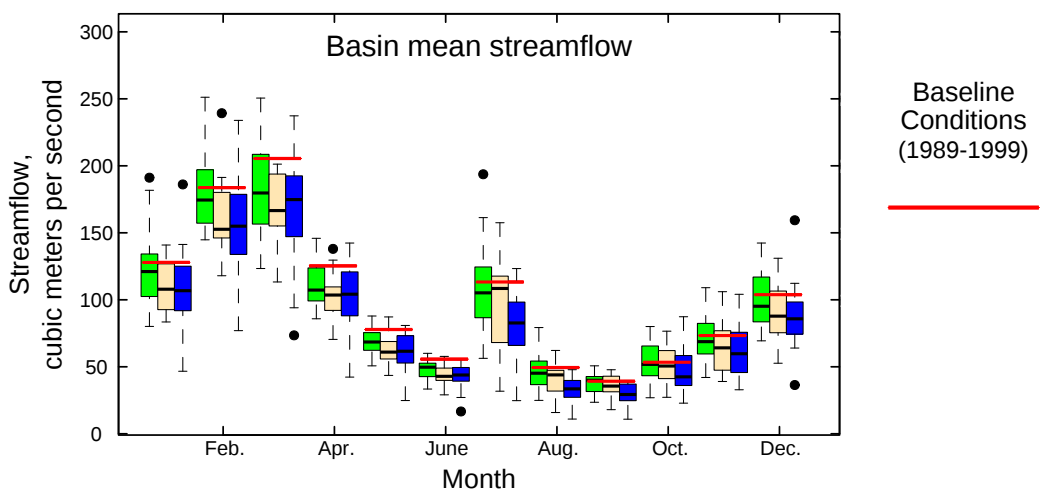

\section{EXPLANATION}

$2030 \quad 2060 \quad 2090$ (2025-2035) (2055-2065) (2085-2095)
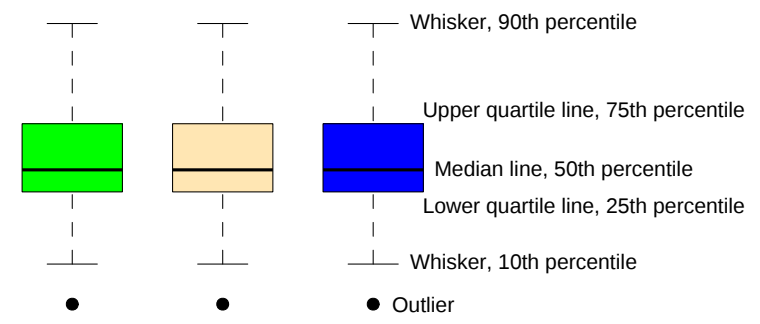

Figure 4. Mean daily streamflow values by month for baseline conditions and projected range $(2030,2060$, and 2090$)$ using the five General Circulation Models and three emission scenarios.

Intermediate states of interest produced by PRMS are summarized in Markstrom and others (2011). Analysis of these intermediate states may indicate which areas of the water balance are most susceptible to changes in climate. For example, figure 5 shows the change in simulated basin mean values of soil moisture. The central tendencies of the PRMS simulations for each of the three emission scenarios project decreases in mean annual soil moisture by the end of the 21st century for the A1B and A2 emission scenarios (table 3), though the uncertainties associated with these projections are large and increase with time.

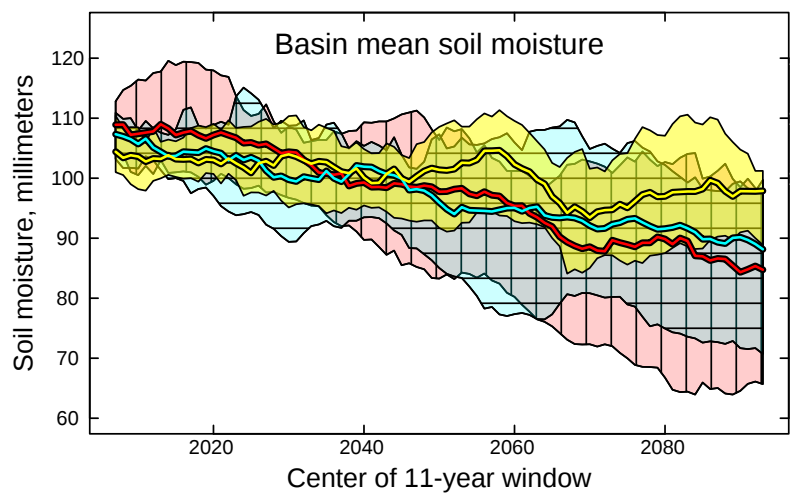

Figure 5. Projected range in 11-year moving mean daily values of soil moisture by emission scenario. 


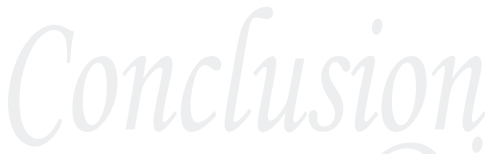

\section{Conclusion and Discussion}

In the upper Flint River watershed, increasing demand for water from the steady growth of the Atlanta Metropolitan Area has the potential to alter streamflow throughout the watershed. Increased development, combined with severe droughts in the area, has already resulted in shortages and restrictions on the limited surface-water supplies.

The broader-scale effects of climate change on the flow regime of the Flint River indicate a slight drying of the watershed, but the variability associated with the magnitude of this projected drying is large. These results did not consider potential future land-cover dynamics. They also do not answer the question of whether the potentially adverse effects because of climate change, combined with the added urbanization stresses, can be mitigated with careful land-use planning in the Flint River Basin. The combined effects of climate change and urbanization on the Flint River may alter both the quantity and timing of streamflow and have the potential to change the conditions that support biological diversity in aquatic communities. The scientific techniques described in the fact sheet can be augmented with other techniques in developing the science needed to address the combined effects of climate and landcover dynamics on streamflow regimes.

\section{By Lauren E. Hay and Steven L. Markstrom}

For more information visit the following Web sites:

http://wwwbrr.cr.usgs.gov/projects/SW_MoWS/

http://pubs.usgs.gov/fs/2006/3114/

http://ga.water.usgs.gov/

http://www.usgs.gov/climate_landuse/

\section{Selected References}

Hay, L.E., Markstrom, S.L., and Ward-Garrison, C.D., 2011, Watershed-scale response to climate change through the twenty-first century for selected basins across the United States, Earth Interactions, v. 15, 37 p.

Intergovernmental Panel on Climate Change, 2007, Summary for policymakers, in Climate change 2007-The physical science basis, Contributions of Working Group 1 to the Fourth Assessment Report of the Intergovernmental Panel on Climate Change: Cambridge and New York, Cambridge University Press, $18 \mathrm{p}$.

Markstrom, S.L., Hay, L.E., Ward-Garrison, C.D., Risley, J.C., Battaglin, W.A., Bjerklie, D.M., Chase, K.J., Christiansen, D.E., Dudley, R.W., Hunt, R.J., Koczot, K.M., Mastin, M.C., Regan, R.S., Viger, R.J., Vining, K.C., and Walker, J.F., 2012, An integrated watershed scale response to climate change for selected basins across the United States: U.S. Geological Survey Scientific Investigations Report 2011-5077, 142 p.

Viger, R.J., Hay, L.E., Jones, J.W., and Buell, G.R., 2010, Accounting for large numbers of small water bodies in the application of the Precipitation-Runoff Modeling System in the Flint River Basin, Georgia: U.S. Geological Survey Scientific Investigations Report 2010-5062, 37 p. 